\title{
THE EARLY BRITISH ADMINISTRATORS IN THE MALAY STATES, 1874-1909
}

\author{
SivachandralingamSundara Raja
}

\begin{abstract}
British intervention in the Malay States began in Perak with the signing of the Pangkor Agreement of 1874 which provided for the appointment of an official Resident whom the British could rely upon for advice. J.W.W. Birch became the first Resident of Perak. Later in the same year, British authority was extended to Selangor and Sungai Ujung, and in 1888 to Pahang. British intervention led to rapid economic growth in the four Malay States, the pace of which was accelerated through Colonial Office support for investments following the formation of the Federation in 1896. However there were conflicts between officials at different levels of the command chain in regards to approval for capital investments in the Malay States. The policies of the administrators differed, as was clearly evident in the agriculture and mining sectors. It is therefore pertinent to understand what led to such contradictions in the decision making process and whether the officials' backgrounds could have influenced their attitudes towards the administrative, economic and social policies that were enforced in the Malay states. This article will explore such conflicts and analyse their underlying causes, and thereby will help explain how colonial administration and administrators shaped the course of British imperial history.
\end{abstract}

\section{Introduction}

The term 'Victorian Age' in British history is synonymous with colonial expansion and its remarkable achievements in literature, science and public education. It was against this backdrop that British statecraft and power succeeded in gaining a firm foothold in the Malay Peninsula. Many of the administrators of this era believed that good government depended on personal qualities and, not on training. The empire was held together by a sense of loyalty among the administrators, who abided by certain standards, and not to a centralized system of administration. The emphasis was rather more on the public spirit. The paternal care of the District Officer was far more important than the activities of metropolitan organizations. This meant that the administrator's policies were bound to differ. This was clearly seen in the agriculture and mining sectors of the Malay States in the late 1890s. As such, a study would be pertinent in understanding whether the officials backgrounds have influenced their attitudes towards administration, economic policies and social aspects in the Malay States from the days of intervention, until the formation of the Federal Council in 1909. 


\section{British Intervention and Economic Development in the Malay States, 1874-1909}

British intervention in Perak (under the Pangkor Agreement in 1874) saw the appointment of an official Resident whose advice needed to be sought by the British. J.W.W. Birch became the first Resident of Perak. Later in the same year, British authority was extended to Selangor and Sungai Ujung, and in 1888, to Pahang. ${ }^{1}$ The official intervention witnessed the four Malay States undergoing rapid economic growth under the British hegemony. Economic activities were mainly focused on tin mining and commercial crops. The state of Perak became an important producer of tin with the finding of lode by Long Jaafar in 1848. Besides tin, the planting of crops such as coffee, tapioca, gambier, pepper and sugar cane were officially encouraged. The other states too were involved in tin mining and the planting of similar agricultural products.

In terms of administration, from 1874 - 1896, the four states were administered by Residents under the purview of the Colonial Office. Until 1895, the Residents of the four states were subordinate only to the Governor of the Straits Settlements in Singapore, to whom they submitted their journals of proceedings, annual reports and budget. Often the Governor was ignorant of the Malays and their affairs. ${ }^{2}$ This was mainly due to lack of proper communications. In addition, the lack of proper roads and railways made extended tours extremely difficult and, correspondence was subject to great delay. As such, it is not surprising to note that serious differences existed in the administration of justice and in matters relating to taxation and land settlement; and the laws passed by the several states were very often found to be at variance with one another. ${ }^{3}$

Though the four states witnessed development, the individual Resident in the respective state went his own way. This thus gave rise to the need for central control, and led to the idea of forming a federation in the late 1890s. This was clearly stated by Swettenham: "... each Resident went his own way and was inclined to resent either suggestion or interference. Some important matters, such as the system of revenue farms, the amount of tin duty, and the rate of quit rent on Government lands, had been established, as regards principle, in the earliest days, and only details were open to varying treatment. .... as time went on and the States grew in importance, these differences, at first irritating, became unbearable and led to federation"."

Federation witnessed a more closer form of administration with standardisation and uniformity in land and mining laws, as well as other aspects of administration from 1896 -1909. Tremendous growth was seen in both the mining and agriculture sectors. ${ }^{5}$ The development of these sectors was mainly attributed to the encouragement given by the Governments of the respective Federated Malay State.

\section{Administration and Administrators of the Malay States}

In terms of administration, with the formation of the Federated Malay States, the four Malay states, i.e., Perak, Pahang, Selangor and Negeri Sembilan, were centralized under a Resident-General at Kuala Lumpur, answerable to the Governor cum High Commissioner in Singapore. The Governor was bestowed two titles: firstly, as Governor in the colony and secondly, as the High-Commissioner in the Federated Malay States. The Governor/High- Commissioner was answerable to the Colonial Office in England. ${ }^{6}$

It is also interesting to note that, from the late $19^{\text {th }}$ to early $20^{\text {th }}$ century, more European estates and mines were opened in the Malay States, and with that, both groups 
played a vital role in promoting investments and had a bigger say in government policy. ${ }^{7}$ The number of Europeans too increased in the Malay States. Europeans in the Federated Malay States in the year 1911 totalled 3,284, most of whom were based in Perak and Selangor. ${ }^{8}$ The number of Europeans involved in agriculture, mining and commerce in 1901 was 899 , subsequently increasing to 2,112 in the year 1911 . This could explain why there was a big change in British policy with regards to investment in the Malay States.

Although the Colonial Office policy was to encourage investment, there were however many occasions when the administrators (be it the Residents, Resident-Generals or the High Commissioners) were indifferent to the investors. This could be seen from the time of the Residential System, to the Federation, and the years thereafter.

It is important to bring to light the background of the administrators in order to understand their indifferences. The differences in attitudes or policies of the administrators were very much related to their educational background and the school of thought they belonged to. The officials who came to administer the Malay States from 1896-1914 were Englishmen who were mainly from the upper middle class. Most of them were tutored privately and held university degrees. Frank Swettenham was of middle class origin; George Maxwell and J.P. Rodger from upper middle class; while Hugh Clifford and Martin Lister were likewise, sons of minor aristocracy. From 1896 onwards, the majority of Malayan Civil Service cadets were from public school and most were well educated. ${ }^{9}$ According to Butcher, most of the civil servants in the Federated Malay States from 1874 -1914 attended English public schools such as Eton, Winchester, Harrow, Rugby, Shrewsbury, Charterhouse and Westminister. ${ }^{10}$

These Englishmen by birth or education, were known as "gentlemen". The gentleman's ideal lifestyle involved "the marriage of social position with public service, privilege with duty, loyalty with honour and outer propriety with inner virtue". ${ }^{11}$ For Wilkinson, “...the gentleman's behaviour was group-directed, class-directed and community-directed". 12 This political elite who were known as gentlemen helped the government to make the public service a gentlemanly obligation and by doing so, was able to defend its identity, political power and social prestige as an elite group, which had a grip on public affairs.

The gentleman's value pushes the concept of white man's burden. ${ }^{13}$ The gentleman's characteristics were noticeable in the civil service, and his views on society and policies. Attempts were also made to uphold the gentleman's lifestyle in Malaysia. Clubs were founded exclusively to retain their upper/middle-class lifestyle. For example, in the 1890s, two clubs, i.e. Selangor Club and Lake Club, were formed exclusively for Europeans. Besides, there were also cricket, golf and hunting clubs. ${ }^{14}$

\section{The Victorians and the Fabian School of Thought}

Victorian was a term applied to the mid and late $19^{\text {th }}$ century England, covering the reign of Queen Victoria (1837-1902). The Victorians created the largest empire the world had ever seen. By the 1860s, it covered 9.5 million square miles and included almost 150 million people, the vast majority of them living in India. ${ }^{15}$ The Queen was seen as a symbol of success, self-confidence and expanding nationhood. It was however, at this time that the Democratic principle, the claim that political power should be under the control of all men, irrespective of wealth or status, became an objective of political leaders. This development was accompanied by the growth of new thinking on the role of 
the state. Political reformers emerged who campaigned for the state to intervene and protect the people. Reformers wanted the state to accept greater responsibility for the welfare of individuals.

The Queen strongly believed that, "coloured races should be treated with every kindness and affection, as brothers, not-alas! Englishmen too often do...". 16

The attitude of the administrators was also influenced by the political thoughts of the Fabians which believed that whatever the government does must benefit the natives. It was also believed that most of these Victorian administrators were followers of the Fabian school of thought, which consisted of a largely middle-class group established in 1884 to spread socialist ideas in Britain. The society played an important role in founding the Labour Party. As a term, it came to be applied to supporters of gradual social reform. The leaders of Fabians at that time included Lord Curzon, Lord Selborne, C.J.Rhodes, L.S.Amery, Josiah Wedgwood, Joseph Chamberlain [was the Secretary of State for Colonies from June 1895 - October 1903], Bernard Shaw, Rosebery and Milner. ${ }^{17}$

To quote Peace, "The Fabians too believed that aboriginal backwardness and efficiency must not be permitted to obstruct the advance of international civilization and development". ${ }^{18}$ For the Fabians, the question of colonial exploitation or imperial dominion did not arise at this time. For them, it should be the partnership between the races, later known as Commonwealth. It was also termed as enlightened and progressive. $^{19}$

According to Benians,

The Fabians desired to see the Empire as a powerful and self conscious force planned energetically for the exploitation of resources and united more closely as trustees for British standards in the common interests not only for the whole British Commonwealth, but of the whole of civilized society. ${ }^{20}$

Joseph Chamberlain who was the Secretary of State for the Colonies from June 1895 - October 1903 was a Fabian. The Fabian thoughts were reflected in his debates in the House of Commons on 22 August 1895.

Underdeveloped estates could never be developed without Imperial assistance ... cases have already come to my knowledge of colonies which have been British Colonies perhaps for more than a hundred years in which up to the present time British rule has done absolutely nothing ... I shall be prepared to consider very carefully myself, and then, if I am satisfied, confidently submit to the House, any case which may occur in which by the judicious investment of British money those estates which belong to the British Crown may be developed for the benefit of their population and for the benefit of the greater population which is outside. $^{21}$ 
It was not surprising to see British colonial administrators of this period helping the natives to build irrigation and drainage, as well involved in sanitation and health programmes. This explains why some of the administrators in the Malay States in the 1890 s were sympathetic to the cause of the natives.

\section{The Victorian Administrators and the Malay States: Conflict between British Administrators with Regard to Administration, Economic and Social Policy}

A few cases in the Federated Malay States will be discussed to highlight the undoubted fact that the British administrators who were sympathetic to the cause of the locals were influenced by the Victorian thoughts of the day.

\section{Case Study in the states of Perak and Negeri Sembilan}

The attitude of the Resident of Perak, E.W.Birch ${ }^{22}$ who was sympathetic towards a Sakai who applied for land in the state in the 1890s explains the fact that his background influenced his decision. Charles Alma Baker ${ }^{23}$ was a prominent businessmen in the state, but his application was rejected when the Resident strongly felt it was the Sakai's birthright to work on his land. Charles Alma Baker wanted to introduce the dredging system in Perak which he felt would contribute greatly towards the development of the state. (Alma Baker's Company enjoyed a good track record as the world's largest operator of tin mines at that time. $)^{24}$

In this case, Alma Baker applied for prospecting licence for more over 800 acres, over and above the original concession. Although initially the prospecting licence was approved, it was unfortunate that the licence was ultimately never granted to him, although he was made to wait for more than a whole year. The application was delayed in the Kinta Land Office for some 18 months "on account of Sakai claims". ${ }^{25}$ Finally his application was cancelled, and the land was handed back to the Sakais.

Alma Baker was shocked, for he had not anticipated such a turn of events. He had spent a great deal of his own money for prospecting tin, and he stood to lose a fortune through this misadventure. He had complied with terms for which he was granted the concession to prospect tin over the 800 acres, approved by the Resident. The District Officer then enquired whether the Resident could grant Alma Baker a prospecting licence elsewhere. ${ }^{26}$ When the Acting Resident forwarded Alma Baker's application (for a prospecting licence over an alternative site covering some 800 acres), the ResidentGeneral replied on $26^{\text {th }}$ May 1904 that since the Kinta mining application book was still closed, Alma Baker should not be authorised to select an alternative area for prospecting purposes. When Alma Baker asked for a reconsideration of his application, the Acting Resident informed him by a letter dated $30^{\text {th }}$ July 1904 that if he was dissatisfied with the Resident-General's decision, his remedy was to send a petition to the High Commissioner.

When the matter was referred to the High Commissioner by the Resident-General, the former felt he was unable to interfere in the matter. The High Commissioner's reply revealed his feelings that Alma Baker had been victimised or else he would have 
endorsed the decision of the Resident and the Resident-General. This was not the only case where Birch was seen to be sympathetic to the cause of the natives. There were other incidents where he had shown sympathy towards the natives. One such case was in Negeri Sembilan where he strongly supported irrigation schemes for the Malays.

In his memorandum addressed to the Resident-General in early April 1896, he reasoned out why there was a need to carry out irrigation schemes in the Malay States. It was obvious that the amount of money spent to import rice was high compared to the money spent on cultivating rice locally. ${ }^{27}$ Besides that, local cultivation of rice would also help to create permanent settlement.

The Resident in his memorandum listed out valid reasons why agriculture should be carried out in the Malay States. He felt that the natives (Malays) should be helped to settle permanently, and to make their means of livelihood secure in the production of their great staple commodity. Towards this end, it was the duty of the Government to prepare unalienated lands which would induce the population of the future to remain settled.

The Resident opposed the notion that the cultivation of rice should not be encouraged because it was not profitable. His argument was that the natives cultivated rice from force of habit and not because it paid them to do so. He further added,

... the bulk of existing rice fields in these countries are the property of the natives of these states, land which has been held by them for generations and which in most cases, is not suited to any other species of cultivation. Surely it is not wrong for these people to cultivate their ancestral lands in the only way in which they can be cultivated, or for the Government to aid them in securing water to enable them to cultivate to the best advantage. ${ }^{28}$

The Resident also stressed that twenty years of experience had taught them that foreigners have not been successful in any agricultural enterprise which had anything to do with land. Therefore it would be the right thing to encourage the natives.

The third point he brought to the attention of the Resident-General was the advantage one would gain from encouraging the Malays to cultivate paddy. Paddy only required six months to work on, and for the rest of the year the cultivators could work at any other occupation. What the natives needed was a regular supply of water, which would help transform some eighty percent of the agricultural immigrants into permanent inhabitants. It would also stimulate the production of various other crops.

The fourth point which many were not aware of was that it was far more expensive to import rice than to cultivate it at home. The amount that was spent by the four Federated Malay States on imports for the year 1897 was six and a half million dollarsthis amount could alternatively been employed in increasing production at home and enriching local producers. On the other hand, the value of agricultural products in terms of exports amounted to only four and a half million dollars. The Resident therefore strongly felt that all efforts must be made to encourage agriculture. 
The fifth point was that almost all the Malay States were suitable for paddy cultivation, on account of their countless streams and innumerable valleys which would help to water the fields. Due to all these advantages, the Resident strongly recommended the introduction of an enactment to regulate the irrigation and cultivation of paddy lands and supply of water in irrigation areas.

The Resident also suggested the formation of a Central Irrigation Board comprising the Resident-General, the four Residents, the Commissioner of Lands and Mines, members of the State Council, State Engineer, Chief of the particular district that was to be irrigated, and the Mukim Councils represented by the Collector of Land Revenue or District Officer, District Engineer, two officials to be nominated by the Resident, the Titular Chief of the District and the Penghulus or Lembagas. ${ }^{29}$

In brief, Birch's memorandum proposed that an official irrigation policy for the Federated Malay States be defined and laid down by enactment, so that the Central Irrigation Board may be empowered to carry out irrigation projects; that the Board members should be appointed and a liberal financial vote allocated to meet the costs of irrigation development. $^{30}$

His sympathy towards the natives were also seen when he was the Governor of North Borneo (1901-1904). He pushed for the Government to review the policy of taxation so that the indigenous people and foreigners would gain from the system. "He initiated a series of basic reforms which were to have profound effect on indigenous society and administration". ${ }^{31}$ Birch created good relations with the natives and was also sympathetic to their cause. This was also brought to light by Lim Teck Ghee in his work, Peasants and Their Agricultural Economy in Colonial Malaya, when he fought for the right of peasants to participate in the rubber boom. ${ }^{32}$

Birch reflected the same attitude in Negeri Sembilan in 1896 when he fought strongly for rice cultivation among the Malays. According to Burns, "His long and continuous interest in the Malay matters, both as a scholar and as an administrator, brought him to the forefront of the Pro-Malay campaign. Indeed, he was the architect of some of the most important proposals concerning the Malays. His most significant contribution was to Malay education, especially his scheme for the creation of the Malay Residential school". ${ }^{33}$ However, there were scholars who were critical of Birch, i.e. J.S. Sidhu $^{34}$ and Heussler ${ }^{35}$ who feel he didn't do anything noteworthy, but the cases highlighted above could shed a different light on him.

From the evidence outlined above, it is clear that Birch's attitudes towards the natives were very much related to the philosophy of the Victorian era.

\section{Case study in the state of Pahang}

In the case of Pahang, J.P.Rodger, the Resident of Pahang (October 1888 - June 1896), is seen as a Resident who was sympathetic to the cause of the natives. He was a strong exponent of Malay rights, and demanded that the Malays be included in the British administration of the Malay States. ${ }^{36} \mathrm{He}$ in fact wrote to the Resident-General suggesting special schools for the rajas and the native chiefs. W.H.Treacher, the new ResidentGeneral of Federated Malay States, made room for the recruitment of natives in the local district. 
Clifford strongly believed that the interest of the natives has to be protected while the interests of the investors were emphasized by the Government of the day. According to Stockwell, "He would like to protect the indigenous inhabitant's interest when emphasis is given on big business". ${ }^{37}$ His stand on this matter was consistent and was noticeable when he served in other colonies like North Borneo. This explains why he was sympathetic to the cause of squatters in Pahang and the Sakais in Negeri Sembilan. In fact when Clifford served in North Borneo, he strongly voiced for the man on the spot to have his independence and say. To quote Clifford, "In the eyes of the men who do their country's work on the outskirts, telegraphy, seen in the light of a bitter experience, is the most abominable of human inventions. Fettered to the little ticking instrument by miles of thin wire, a man loses all power of initiative; the passion for personal responsibility, which has had so much to do with the formation of the characters that have made England's rule in Asia a possibility, is scotched or slain; by the agency of the telegraph the man at a distance is enabled to override the recommendations of the man on the spot - the man, be it noted, who is best able to form an opinion; by its aid a centralization is created which, had it existed from the beginning, would infallibly have choked the life out of our eastern Empire while it was still a pulling thing in swaddling clothes". ${ }^{38}$ This was also agreed upon by Huessler, who says, "There is no doubt Clifford was his own man". 39

In his writings from 1901-1903 which appeared in newspapers and periodicals, he attacked the insensitive approach taken by the Dutch towards the natives in Acheh, Americans in the Philippines and the British in the Malay States. ${ }^{40}$ Although scholars like Allen and Heussler are of the opinion that Clifford was a traditionalist (who took a rather romantic view of Malay village life, and tended to exaggerate the abuses of Malay aristocratic rule), the fact remains that his view that imperial rule should treat natives with care, has been consistent.

\section{Conclusion}

From the above discussion and case studies, it is obvious that some of the administrators in the Malay states were sympathethic to the cause of the natives. A further examination of their backgrounds does bring to light the fact that this was due to the Victorian philosophy of the time which believes that adminstrators have to be independent in their decision-making, and one has to rule for the betterment of its people. A further study into many of the British administrators of the Malay states would undoubtedly strengthen this belief/thesis.

\section{Notes}

1 C.M.Turnbull, "The Origins of British Control in the Malay States Before Colonial Rule", in J. Bastin and R. Roolvink, Malayan and Indonesian Studies, Oxford: Clarendon Press, 1964, p. 170.

2 Emily Sadka,The Protected Malay States 1874-1895, Kuala Lumpur: University of Malaya Press, 1968, pp. 188-189.

3 Ibid. 
4 F.A.Swettenham, British Malaya, An Account of the Origin and Progress of British Influence in Malaya, London, John Lane Company, 1906, p. 251.

5 Chai Hon-Chan, The Development of British Malaya 1896-1909, Kuala Lumpur: Oxford University Press, pp. 143-196; Wong Lin Ken, The Malayan Tin Industry to 1914, Tucson: University of Arizona Press, 1965, p. 249 and J.H. Drabble, Rubber in Malaya, 18761922, The Genesis of the Industry, Kuala Lumpur, Oxford: University Press, 1973, p. 215.

${ }^{6}$ Jagjit Singh Sidhu, Administration in the Federated Malay States, 1896-1920, Kuala Lumpur: Oxford University Press, 1980, pp. 41-48.

7 J.G. Butcher, The British in Malaya 1880-1941, The Social History of European Community in Colonial South-East Asia, Kuala Lumpur: Oxford University Press, 1979, pp. 14-18.

8 Ibid., p. 27.

9 R. Stevenson, Cultivators and Administrators, British Educational Policy towards the Malays 1875-1906, Kuala Lumpur: Oxford University Press, 1975, p. 74.

10 J.G. Butcher, The Social History of European Community, p. 34 and Khasnor Johan, The Emergence of the Modern Malay Administrative Elite, Singapore: Oxford University Press, 1984, p. 11.

11 P.C. Wicks, "Images of Malaya in the Stories of Sir Hugh Clifford", JMBRAS, Vol. 52, Pt. 1. 1979 , p. 60 .

12 R.H.Wilkinson, "The Gentleman Ideal and the Maintenance of a Political Elite", in P.W.Musgrave, e.d., Sociology, History and Education, London: Methuen \&Co.Ltd, 1970, p. 134.

13 Stevenson, Cultivators and Administrators, p. 74.

14 Ibid.

15 Jane Jenkins and Eric J.Evans, Victorians Social Life, London: Hodder Murray, 2002, p. 6.

16 W.D. McIntyre, The Imperial Frontier in the Tropics, 1865-1875, London: Macmillan, 1967, p. 27 quoted from Queen Victoria to Carnovan 24 Dec.1874, Queen Victoria's letters, London, 1926.

17 Benians, et.al., The Cambridge History of the British Empire, London: Cambridge University Press, 1959, p. 347.

18 E.R. Peace, The History of the Fabian Society, London, Allen \&Unwin Peace, 1925, p. 136.

19 B. Porter, Critics of Empire, London: St. Martin's Press Porter, p. 115.

20 Benians, The Cambridge History of the British Empire, p. 349.

21 M. Havinden, and D. Meredith, Colonialism and Development, London: Routledge, 1993, p. 88 .

22 Ernest Woodford Birch (1857-1929) was born in Ceylon in 1857 and was the eldest son of J.W.W.Birch, first Resident of Perak. He was educated at Hartford Grammar School, Sydney College at Bath, Elstree School and Harrow. In 1874 he went to Oxford but his studies were cut short by the murder of his father in November 1875 . He had a two year attachment with the Colonial Office from 1876-1878. He was appointed as a cadet in the Straits Civil Service from 1876-1878. He served as Second Assistant Colonial Secretary and 
then Magistrate, Malacca, 1878-1892; Selangor Lands Department and Acting Resident, 1892-1893; Government Secretary, Perak, 1893-1897; Acting Resident and then Resident, Negeri Sembilan, 1897-1899; Governor of North Borneo Company 1901-1904; and Resident Perak, 1904-1910, from which post he retired.

23 Charles Alma Baker was born in Otago, New Zealand in 1857 and in 1890 he moved to Perak and here for almost 30 years he made fortunes from contract surveying, tin mining and investment in rubber planting (B.Macdonald, Imperial Patriot, Charles Alma Baker and the History of Limestone Downs, Wellington: Barrie Macdonald, 1993, p. X).

24 "Application by Mr. Alma Baker for a concession of land for dredging by an Australian and New Zealand Process", Acting Resident-General, Federated Malay States to Acting High Commissioner, Federated Malay States, $17^{\text {th }}$ June, 1901, HCO, 1142/1901.

25 Ibid.

26 High Commissioner to Resident-General dated $24^{\text {th }}$ June 1905 , HCO, 1142/1901 (John Anderson was the High Commissioner of Federated Malay States from 1904 -1910).

27 "A Memorandum upon the subject of Irrigation for the Resident-General", CO 273/261 (2).

28 Ibid.

29 Ibid.

30 Ibid.

31 D.S. Ranjit, "The Development of Indigenous Society and Administration in Sabah, 18651941”, Ph.D. Thesis, Department of History, University of Malaya, 1986, p. 151.

32 Lim Teck Ghee, Peasants and their Agricultural Economy in Colonial Malaya, Kuala Lumpur: Oxford University Press, 1977, p. 41.

33 P.L. Burns, Papers on Malay Subjects, Kuala Lumpur, Oxford University Press, 1971, p. 4.

34 J.SJagjit Singh Sidhu, Administration in the Federated Malay States, p.139.

35 R. Heussler, British Rule in Malaya: The Malayan Civil Service and Its Predecessors, $1867-$ 1942, Wesport, Connecticut: Greenwood Press, 1981.

36 Khasnor Johan, The Emergence of the Modern Malay Administrative Elite, Singapore, Oxford University Press, 1984, pp. 14-15.

37 A.J. Stockwell, “Sir Hugh Clifford's Early Career”, JMBRAS, Vol. 49, Pt. 1., 1976, p. 95.

38 Ibid., p. 96 quoted from Bush-Whacking and other Sketches, 1901.

39 Huessler, British Rule in Malaya, p. 91. Refer also Paul Kratoska, Honourable Intentions, Talks on the British Empire in South-East Asia delivered at the Royal Colonial Institute, 1874-1928, Singapore: Oxford University Press, 1983, pp. 224 -256; Emily Sadka, The Protected Malay States 1874-1895, p. 387 and P.C. Wicks, "Images of Malaya in the Stories of Sir Hugh Clifford", pp. 60-64.

40 Stockwell, Sir Hugh Clifford's Early Career, p. 99. 